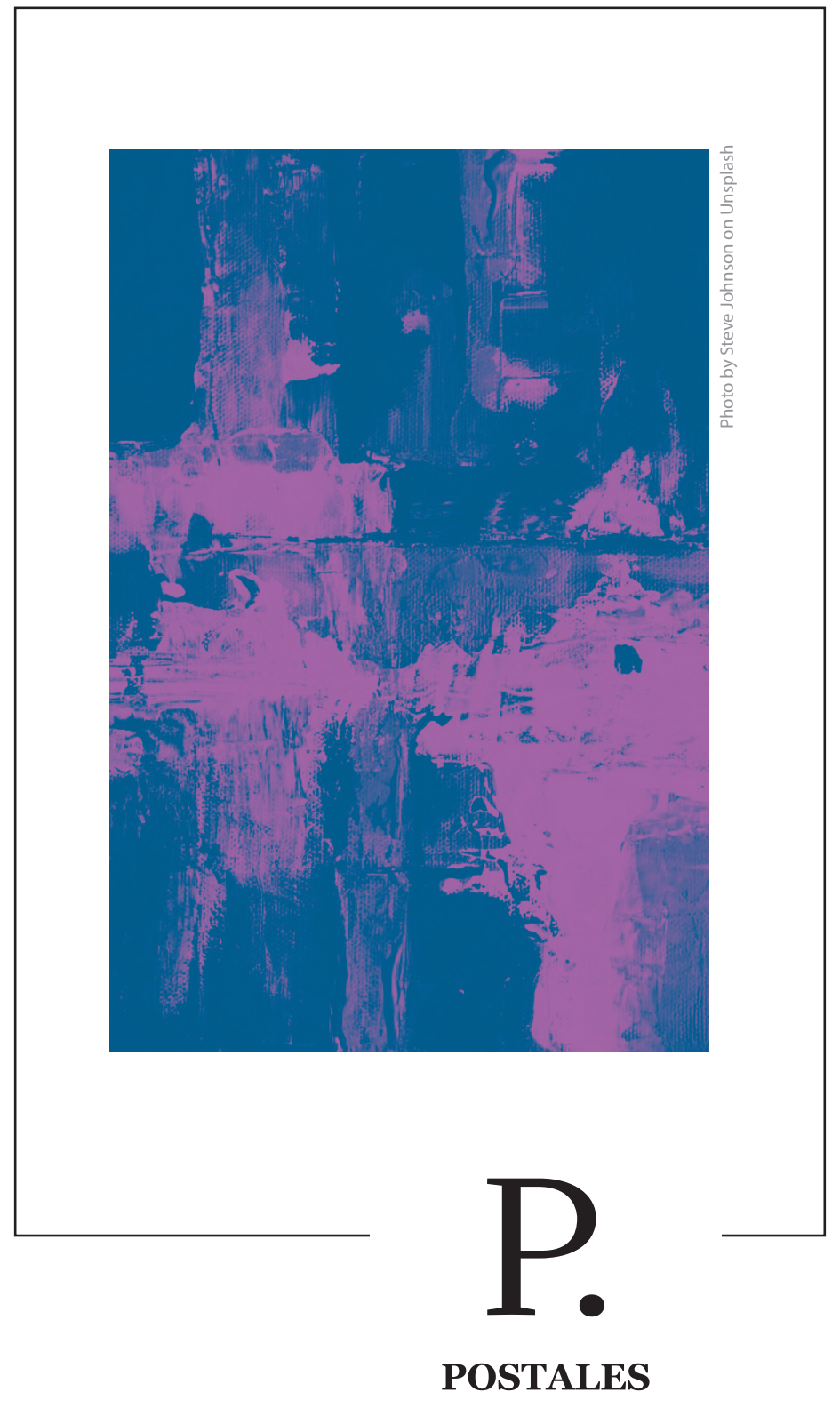


El número anterior de Lienzo daba testimonio de cuarenta años de entrega ininterrumpida de la revista. Ofrecimos un contenido sólido y variado, además de un renovado formato, que no hacían más que reafirmar el compromiso de la Universidad de Lima por continuar aportando una mirada vigilante de nuestra cultura a través de la inventiva artística y la reflexión intelectual. Recordemos que el 2019 fue un año convulso en la vida social y política del país; justamente por ese motivo, publicamos el número de aniversario con la humildad de "brindar al amable lector momentos de serenidad y deleite".

Sin embargo, ni la mente más siniestra hubiera imaginado que meses después sufriríamos la pesadilla de un virus devastador. El presente número de la revista aspira a llegar a los interesados como un estado de tregua en medio de esta incontrolable inquietud. Esta vez cedo el espacio habitual de "Trazos. Palabras del director" a una muestra fotográfica, obra del Círculo de Fotografía de la Universidad de Lima, integrada por jóvenes estudiantes de nuestra casa de estudios, quienes transmutan el quebranto y la incertidumbre de una ciudad sitiada en una vibrante expresión estética. Esta es la secuencia de sus miradas y sus nombres:

"Nueva naturaleza" y "Autorretrato", María Gracia Echevarría / "Monotonía", María Kelly Albornoz Salazar / "Memoria”, Sebastián Cárdenas Loayza / "Naturaleza” y “Extraños", Sandro Meneses Urbina / "Tempestad en la habitación”, Katherine Paola Campos Portilla / "Daydream", Gerardo Teruya / "Autorretrato", Vicente Tintorer Risso / "Barreras" y "Repatriados", Natalia Padilla / "Ruptura", Abril Iberico Mevius / "La intimidad en tiempos de cuarentena", Jackeline Veronik Lockett Salazar / "Mirar ahora”, Evelyn Reyes Choje / “Ma... regresa rápido, por favor”, Alejandra del Águila Grondona. 


\section{Desvíos de la pandemia}

\section{CírCulo de Fotografía de la Universidad de Lima}

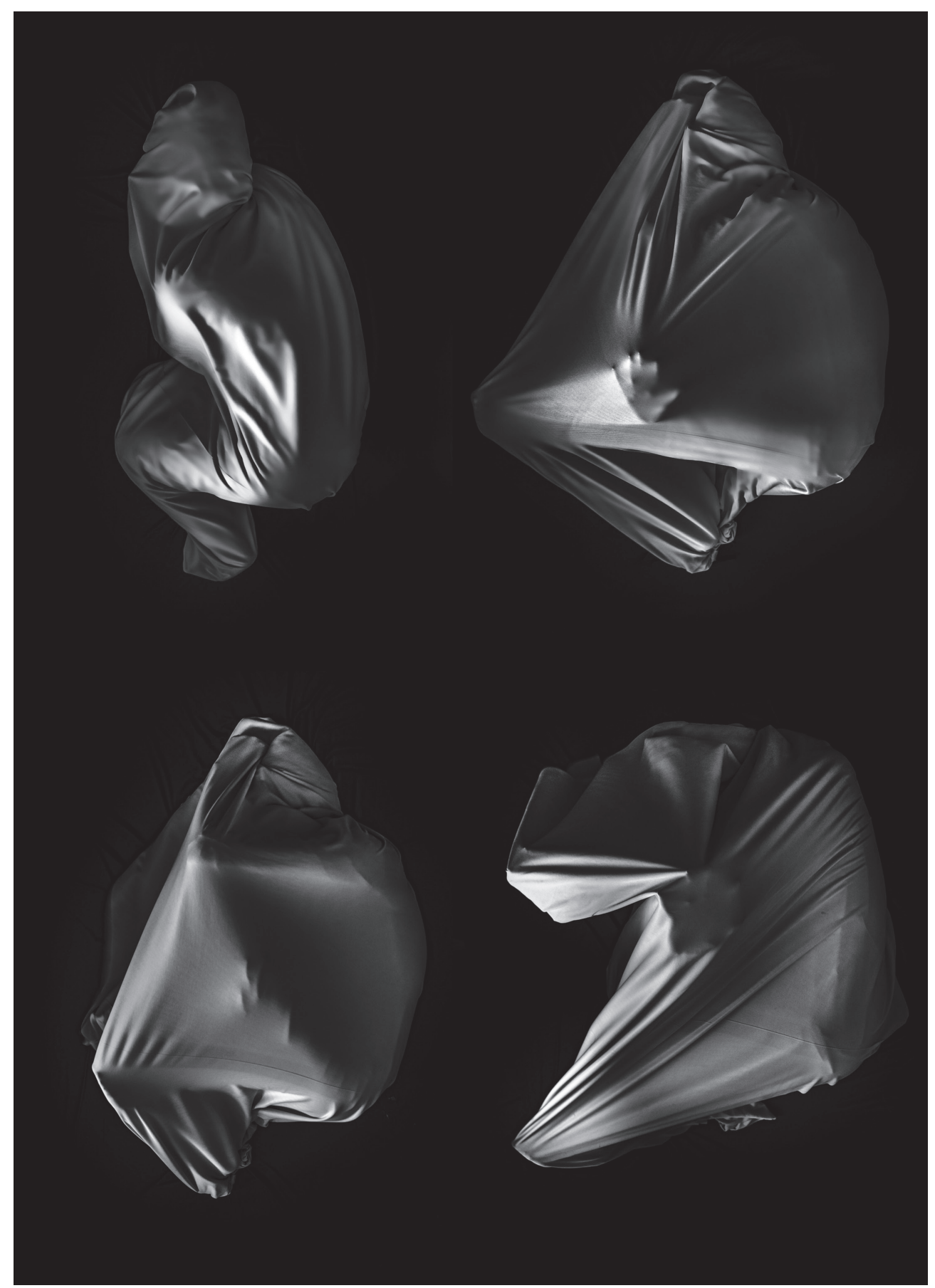



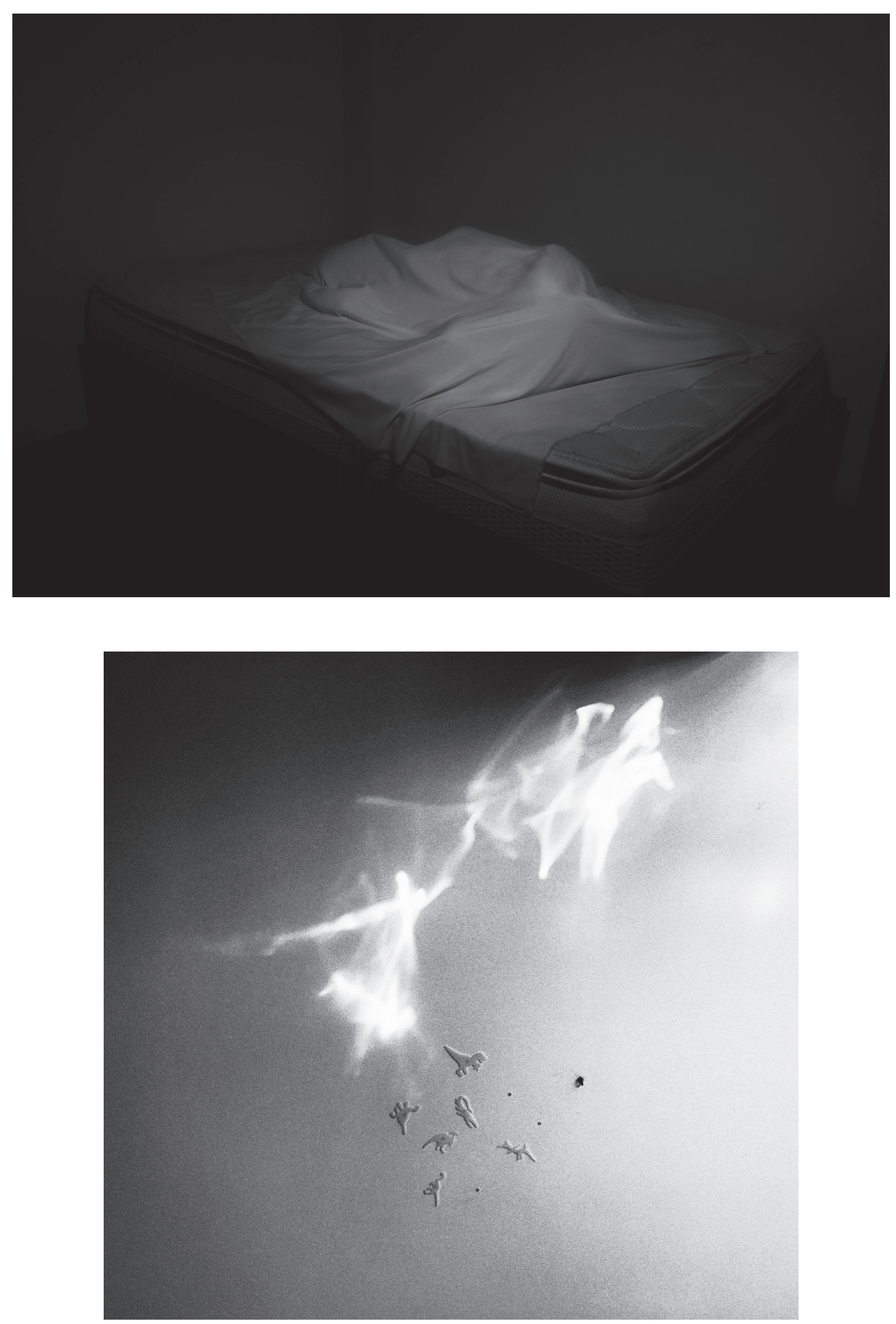
LIENZO 41 / POSTALES
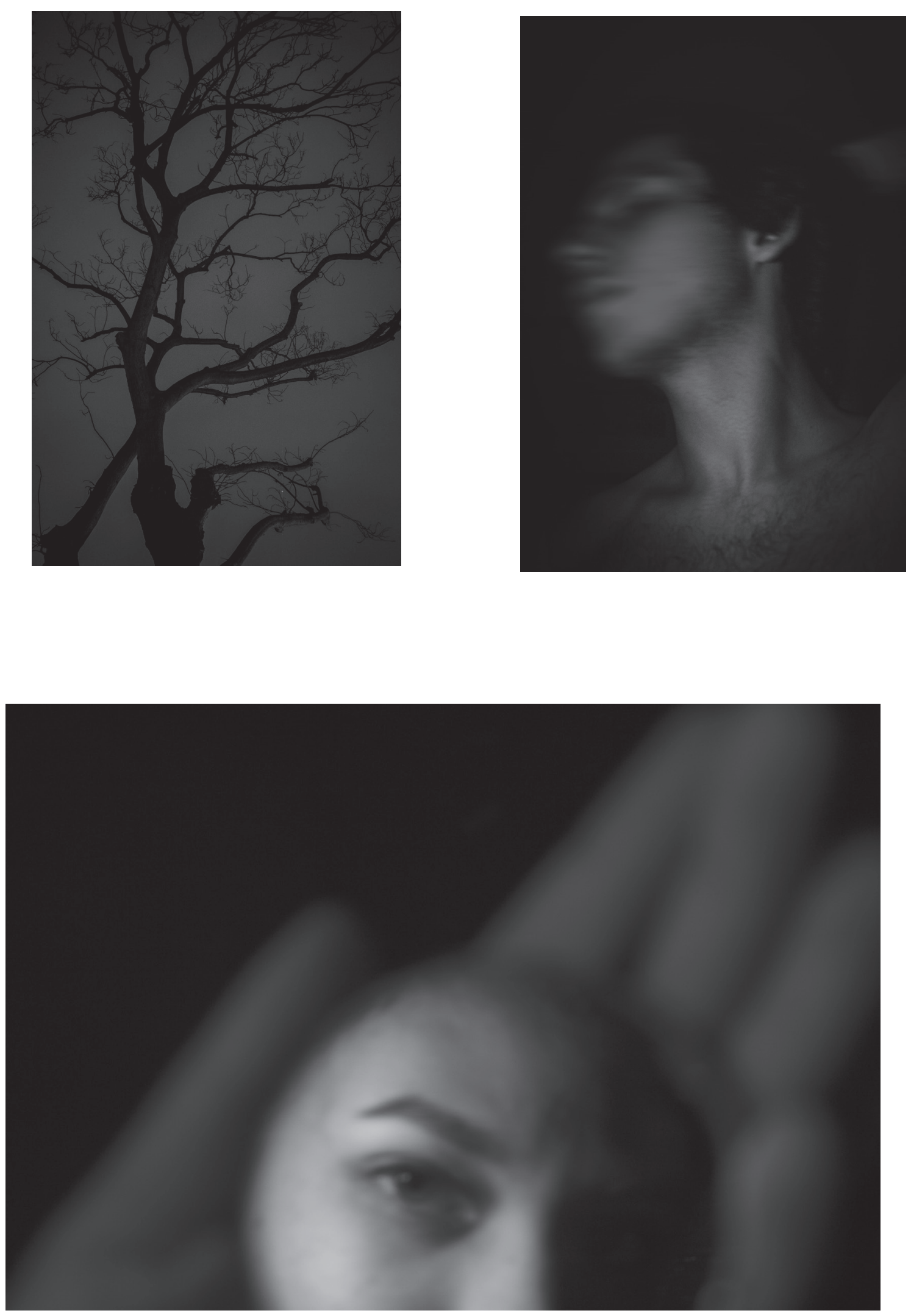
LIENZO 41 / POSTALES
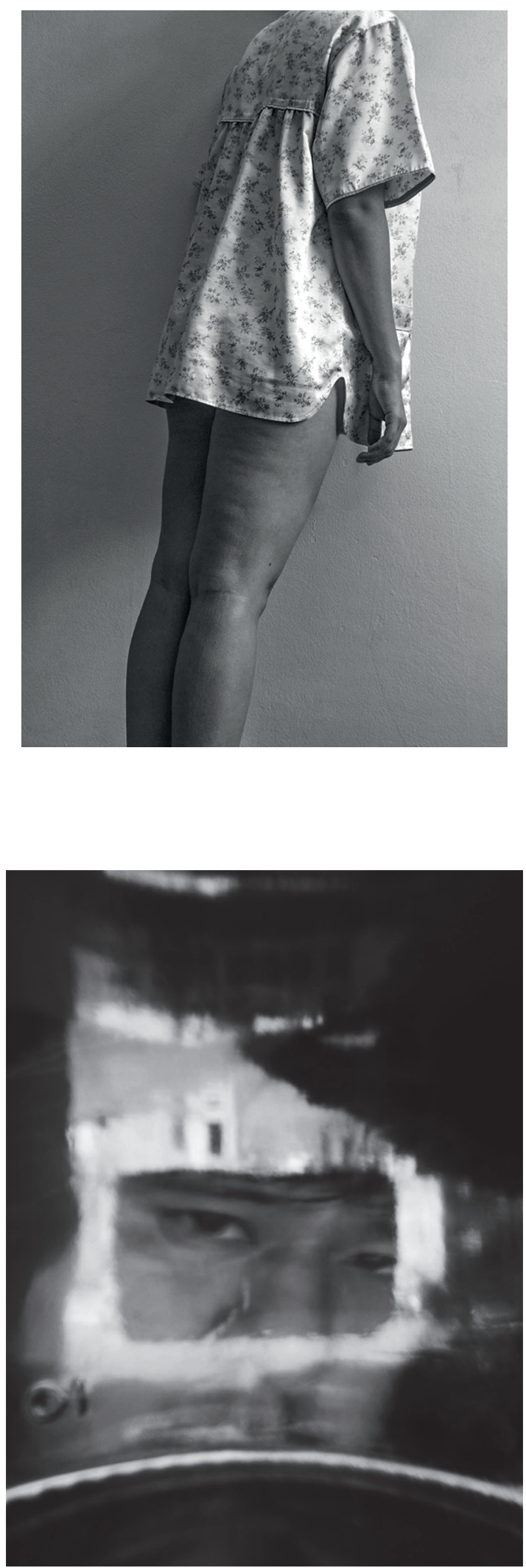


\section{LIENZO 41 / POSTALES}
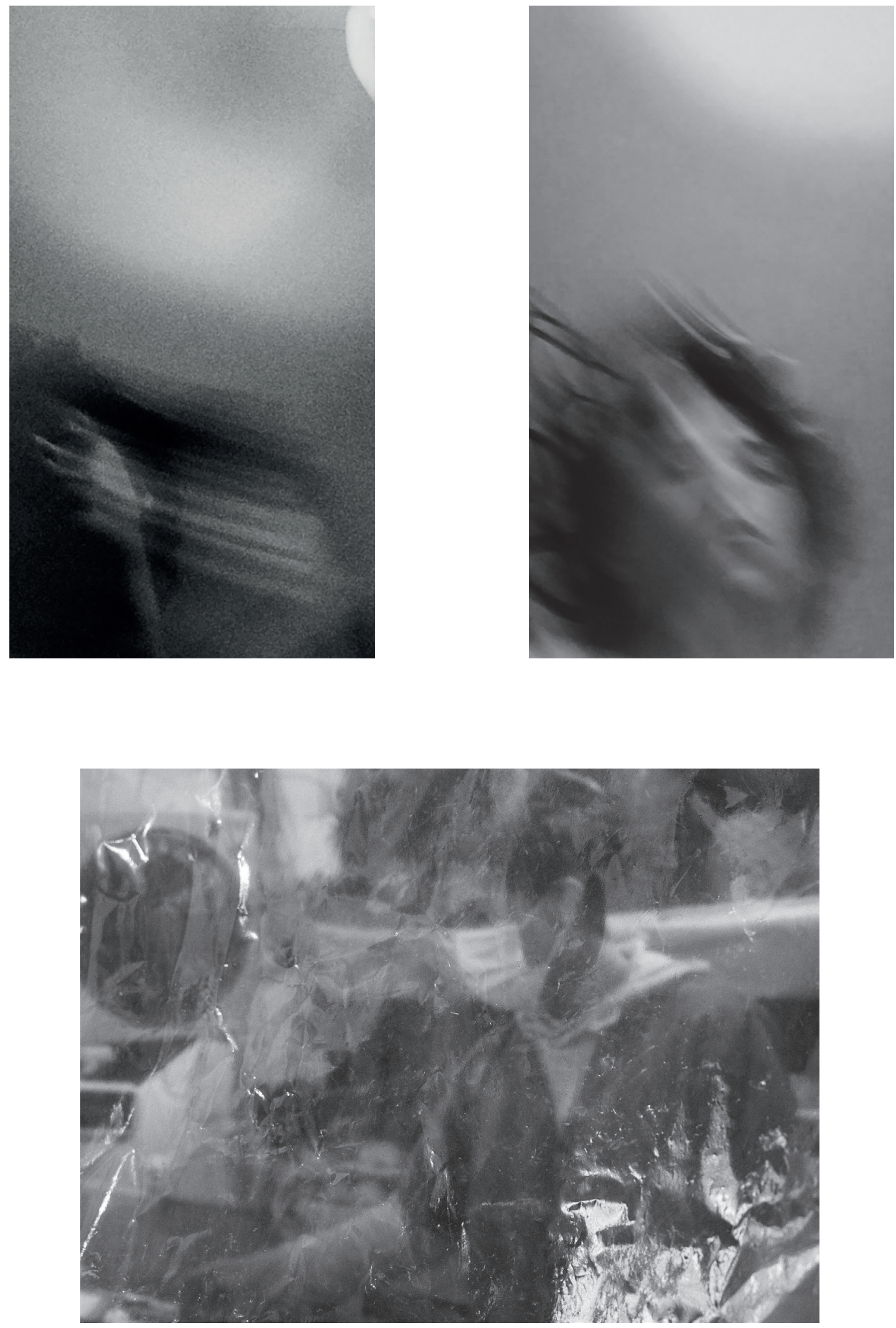

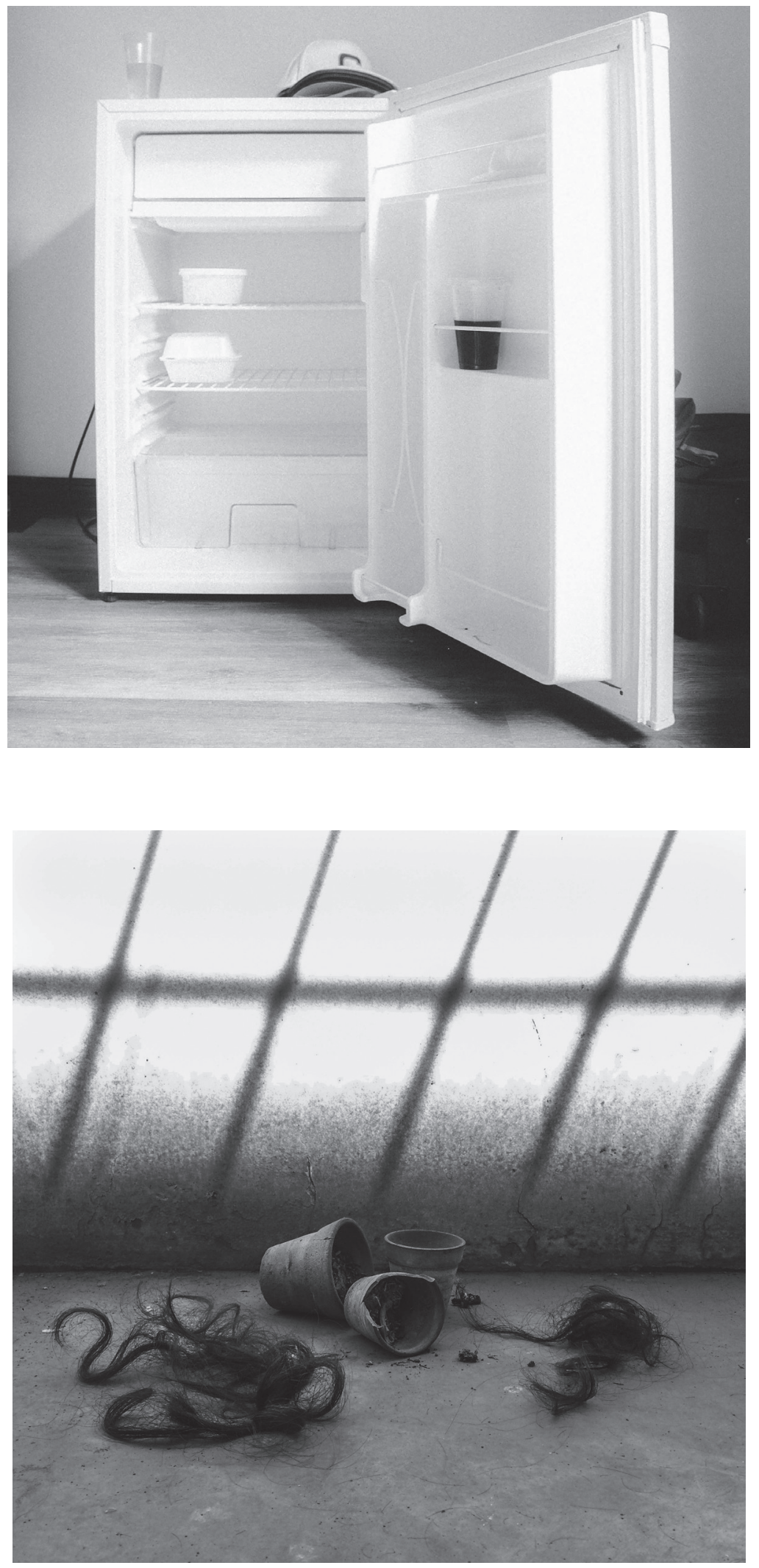
LIENZO 41 / POSTALES
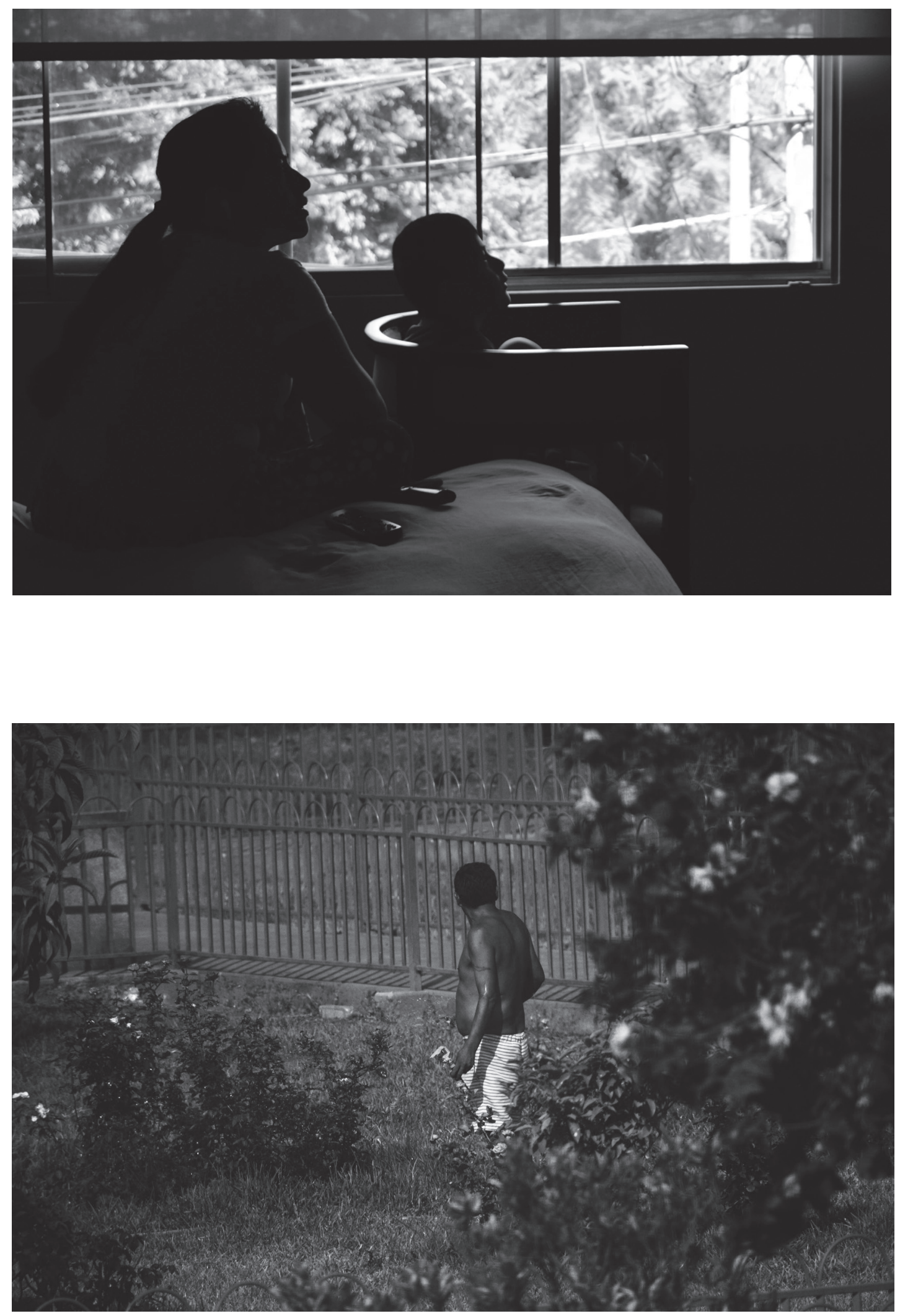


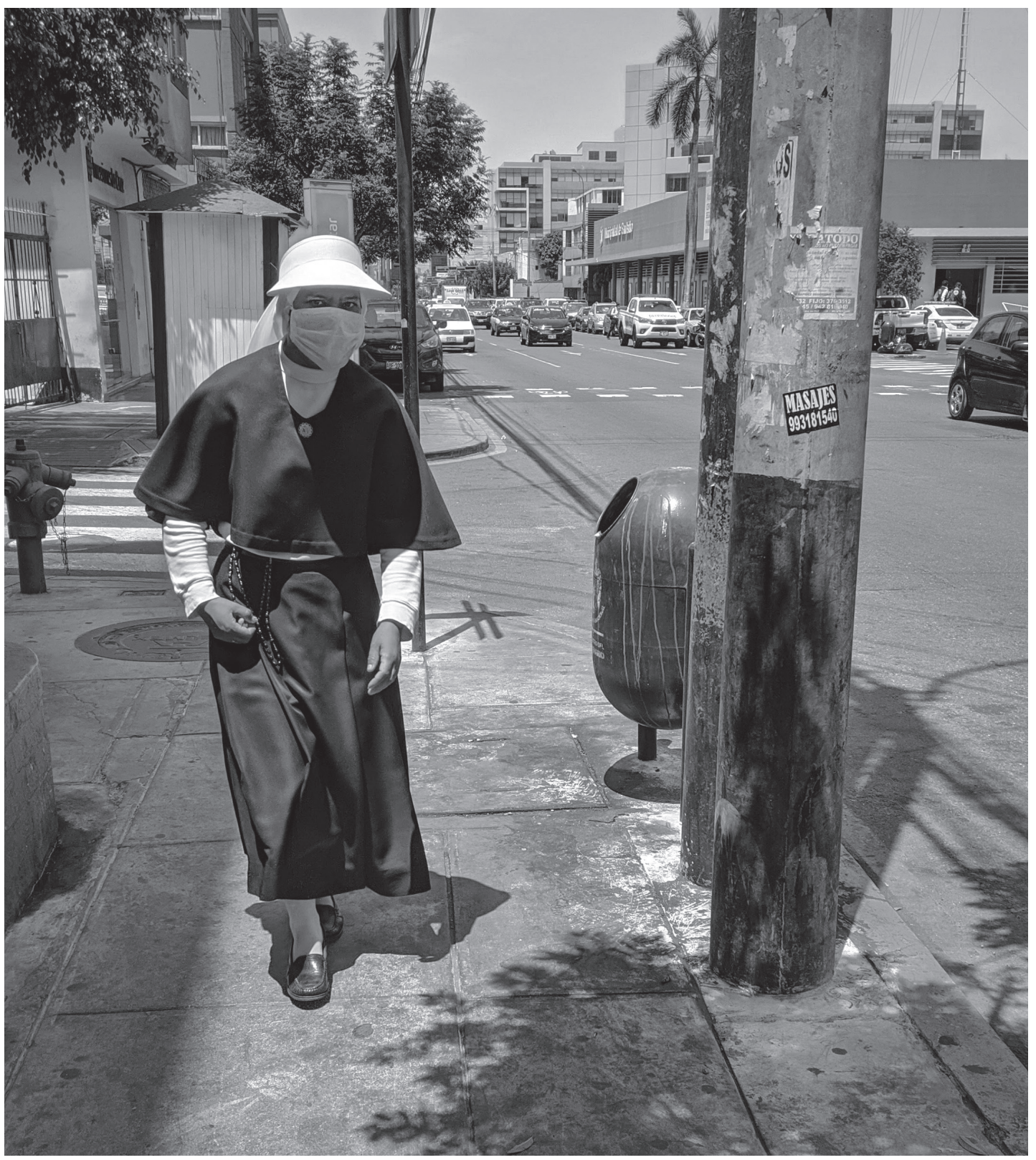



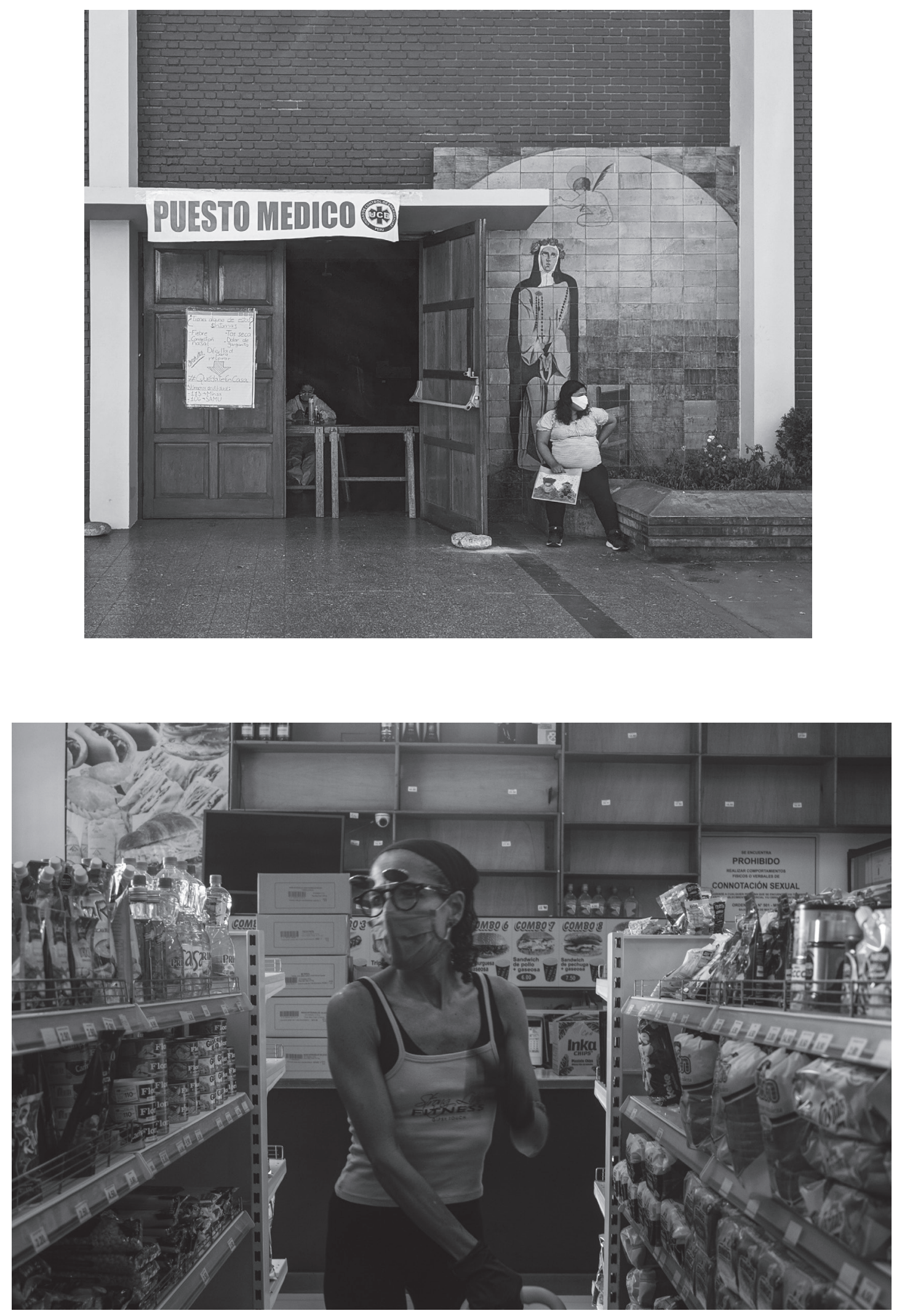


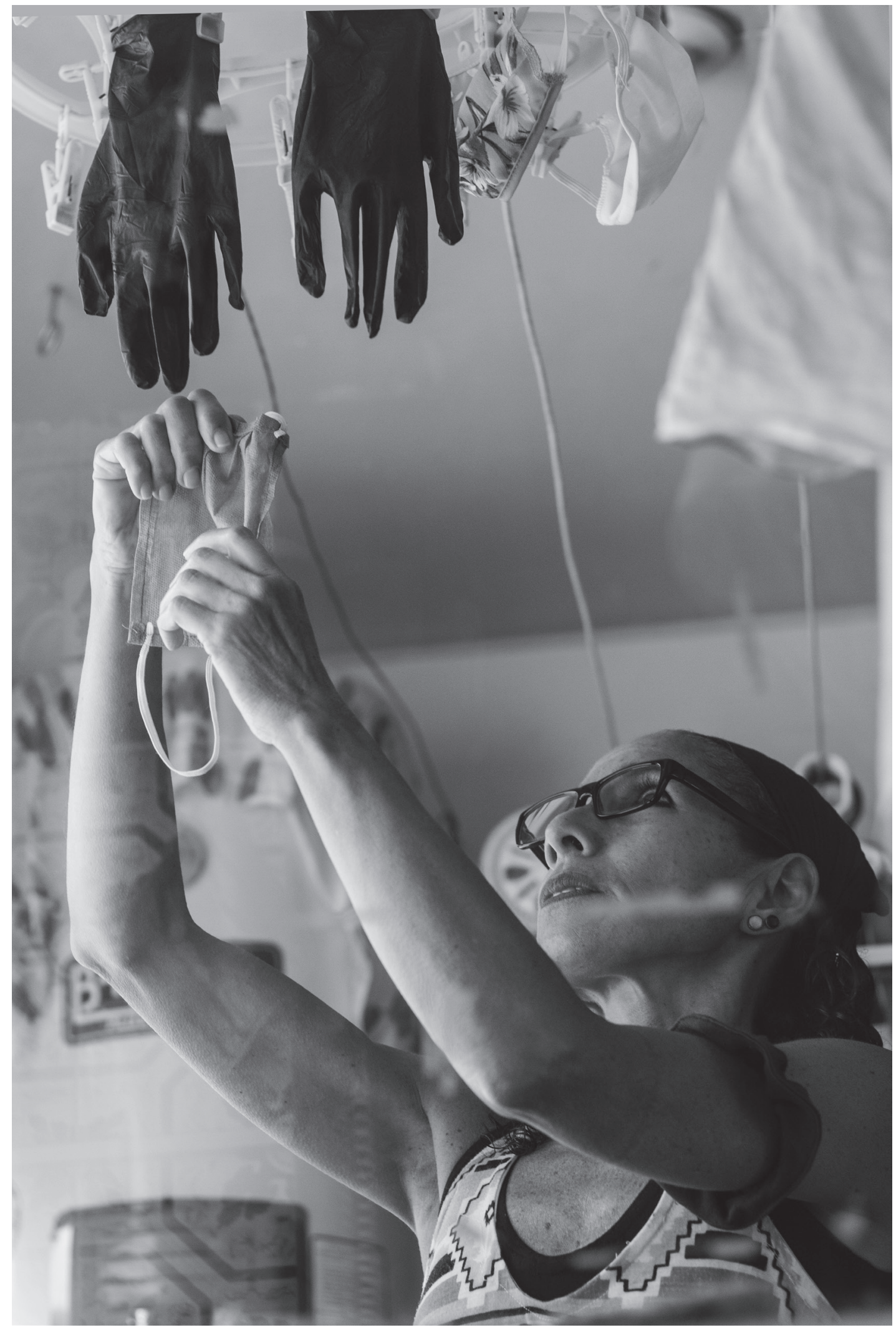

